\title{
Vaccinarea în tuberculoză: prezent şi viitor
}

\begin{tabular}{c}
\hline Olimpia Nicolaescu \\
Spitalul Clinic de Boli Infecţioase şi Tropicale „Victor Babeş“, Bucureşti, România \\
\hline
\end{tabular}

\begin{abstract}
REZUMAT
Mycobacterium tuberculosis (Mtb) infectează aproape 2 miliarde de oameni pe glob, cu 9 milioane de cazuri noi şi 1,5 milioane de decese prin tuberculoză (TB) în fiecare an. Virusul imunodeficienței umane (HIV) este unica boală infecțioasă responsabilă de mai multe decese pe an decât Mtb. O strategie ce combină modalități de diagnostic mai rapide şi mai performante, tratamentul medicamentos şi prevenția (ce include noi vaccinuri) reprezintă singura cale pentru scăderea morbidității şi mortalității TB. Până în prezent, vaccinul Calmette-Guérin (BCG) este singurul vaccin disponibil împotriva TB. În ciuda eficacității sale demonstrate privind reducerea incidenței meningitei şi a TB diseminate la copii, el are o acțiune limitată împotriva formelor pulmonare la adolescenți şi adulți, iar utilizarea sa este nesigură la bolnavii imunocompromişi. Dezvoltarea unor noi vaccinuri s-a accelerat în ultimii 20 de ani, cu mai mult de 10 candidați în variate stadii ale unor studii clinice. Este necesară inițierea unor noi direcții de cercetare, atât pentru îmbunătățirea vaccinurilor existente, precum şi pentru descoperirea unora noi.
\end{abstract}

Cuvinte cheie: tuberculoză, micobacterii, profilactic, vaccin, BCG, studii clinice

\section{INTRODUCERE}

În martie 1993, Organizația Mondială a Sănătății (OMS) a declarat TB o boală cauzată de $M t b$, o urgență globală de sănătate publică. Din 1993 au fost mai mult de 1,5 milioane de decese prin TB în fiecare an. Aproape un miliard de oameni au decedat cu diagnosticul de TB în ultimul secol și TB este cauza principală de mortalitate la bolnavii infectați HIV. Se estimează că o treime din populația lumii este infectată și 5-10\% dintre aceștia vor dezvolta o TB activă; riscul este considerabil mai mare în prezența factorilor predispozanți, în special infecția HIV, dar și a altor factori de risc precum diabetul, insuficiența renală, medicamentele imunosupresive, dependența de fumat și de alte substanțe (1).

În 2015 s-au raportat de către OMS 10,4 milioane de cazuri noi (incidența), dintre care 5,9 milioane (56\%) au fost bărbați, 3,5 milioane
(34\%) femei și un milion (10\%) copii. Incidența cazurilor noi la bolnavii infectați HIV în aceeași perioadă a fost de 1,2 milioane (11\%) din totalul cazurilor de TB (2).

S-au înregistrat un număr de 1,4 milioane de decese prin TB în 2015 și un număr adițional de 0,4 milioane de decese prin TB la bolnavii infectați HIV. Deși numărul deceselor prin TB a scăzut cu 22\% în perioada 2000-2015, TB rămâne una dintre primele 10 cauze de deces în lume (2).

Tuberculoza ridică în vremurile noastre două probleme majore: apariţia formelor cu chimiorezistență, MDR-TB (chimiorezistență la Izoniazidă plus Rifampicină) și XDR-TB (chimiorezistență extinsă), precum și creșterea frecvenței comorbidităților. În 2015 au fost raportate 480.000 de cazuri noi cu MDR-TB și un număr de 100.000 de bolnavi cu chimiorezistență la Rifampicină. Aceștia din urmă se tratează tot ca o MDR-TB, 
fiind demonstrat faptul că $80 \%$ dintre bolnavii cu rezistență la Rifampicină au și rezistență la Izoniazidă (2).

În condițiile descrise se impune urgentarea unor noi metode de diagnostic, precum și diversificarea opțiunilor terapeutice și profilactice. Metodele curente de intervenție pentru prevenirea TB sunt: tratamentul infecției latente (LTBI), cu atenție deosebită pentru copiii sub 5 ani din focarele de TB cu baciloscopie pozitivă, precum și pentru bolnavii infectați HIV; prevenția transmisiei $M t b$ prin controlul riguros al infecției; vaccinarea BCG a copiilor conform Programelor Naționale ale fiecărei țări (3).

\section{RĂSPUNSUL IMUN LA INFECȚIA CU M. TUBERCULOSIS}

Geneza unor reacții patologice în TB este legată obligatoriu de răspunsul gazdei la invazia bacilului tuberculos. Evenimentele care se produc drept urmare a expunerii la $M t b$ se desfășoară în două faze: prima este infectarea cu $M t b$ și, ulterior, dezvoltarea bolii tuberculoase. Pentru cele mai multe dintre persoanele infectate cu $M t b$, răspunsul gazdei constă în împiedicarea multiplicării germenului, situație în care tuberculoza boală nu se mai produce. Tuberculoza se poate dezvolta prin progresia directă a infecției către boală (în 3\% până la 10\% din cazuri, probabil în primul an de la infectare) sau tardiv, la câțiva ani după infecție, fie prin reactivare endogenă, fie prin suprainfecție exogenă (probabil $5 \%$ dintre persoanele infectate fac boala la mai mult de un an după infectare).

Răspunsul imun inițiat după expunerea la infecția cu $M t b$ are o patogenie complexă. Calea principală de transmitere pentru $M t b$ este cea aerogenă prin aerosolizarea unor picături lichide de spută care conțin bacili ce pot fi inhalați. După inhalare, microorganismele ajung în plămânul profund unde sunt fagocitate de către celulele prezentatoare de antigen, macrofagele și celulele dendritice; sub această formă sunt drenate către ganglionii limfatici unde este inițiat răspunsul imun mediat de către celule T $M t b$-specifice. Celulele T-CD4 sunt specifice pentru răspunsul imun la infecția cu $M t b$ și, împreună cu celulele T-CD8 joacă un rol semnificativ în variate stadii ale bolii. Acestea migrează apoi la locul infecției și contribuie la generarea granulomului specific tuberculos. La persoanele imunocompetente, mecanismele de apărare ale gazdei (fagocitarea micobacteriilor de către macrofagele activate imun) previn apariția bolii. Interferonul $\gamma($ IFN- $\gamma)$ și factorul de necroză al tumorilor de tip $\alpha$ (TNF- $\alpha$ ) sunt citokinele esenţiale pentru inducția imunității de infecție. TNF- $\alpha$ contribuie la imunitatea în TB prin activarea activității microbicide a macrofagelor și prin modularea distrugerii celulelor infectate. IFN- $\gamma$ contribuie, de asemenea, la controlul imun în TB prin activarea proceselor microbicide ale macrofagelor, incluzând autofagia, și prin modularea inflamației la locul infecției. Deși multe celule produc IFN- $\gamma$, principala sursă o reprezintă limfocitele, în special limfocitele T de tip CD4+ și CD8+. Interleukina-12 (IL-12) este o altă citokină esențială pentru imunitatea în TB. Cel mai important rol al IL-12 este în diferențierea directă a celulelor T-CD4 în celule T-helper (Th1) care, prin secreția de IFN- $\gamma$, contribuie la controlul TB.

Cunoștințele noastre privind rețeaua de celule imune și citokine puse în joc de gazdă pentru a limita infecția, a genera granulomul specific și a limita extensia leziunilor la țesuturi sunt în creștere și vor asigura o mai bună înțelegere a premizelor necesare generării unei imunități vaccinale eficiente (4).

Baza unui vaccin funcțional este dependentă de abilitatea sistemului imun de „a-și aminti“ întâlnirea cu un microorganism. Caracteristic, memoria imunologică se constituie în urma primei întâlniri cu un germen prin crearea celulelor cu memorie de tip T. Aceste celule T cu memorie sunt specifice pentru fiecare antigen și se localizează în țesuturi și ganglionii limfatici până când, în urma recunoașterii antigenului specific, sunt activate. În cazul unei expuneri secundare 
la antigen, celulele T cu memorie inițiază rapid și imediat un răspuns pentru a elimina microorganismul și a preveni boala. Crearea de celule T cu memorie și a unei imunități de lungă durată se poate obține fie prin expunerea primară la un germen patogen ce a provocat îmbolnăvirea, urmată eventual de vindecare, fie prin vaccinare. Vaccinurile acționează în principal asupra sistemului imun prin expunerea persoanei la o versiune medie, non-letală a antigenelor germenului, astfel încât celulele T cu memorie pot fi generate fără a cauza boala la nivel individual. Ideal, un vaccin este făcut din componente derivate din bacterie care sunt decisive pentru inducerea unei imunități de protecție și în consecință sunt frecvent compuse fie dintr-o versiune atenuată (non-virulentă) sau omorâtă a bacteriei, fie din toxine bacteriene inactivate, sau subunități ale acesteia. Vaccinurile vor avea antigene similare versiunii virulente a germenului, dar le vor lipsi factorii necesari pentru producerea bolii $(5,6)$.

Drept urmare, dacă o persoană vaccinată este expusă secundar acestui set particular de antigene, sistemul imun va elimina rapid patogenul și va preveni boala. Sistemul imun este solicitat să răspundă în mod specific atât la vaccinare, cât și la modificările secundare induse de patogen.

\section{STADIUL ACTUAL AL VACCINĂRII BCG}

Prin cultivarea tulpinilor de M. bovis izolate de la o vacă de către Nocard în 1904, printr-un număr total de 231 de treceri pe o perioadă de 13 ani, pe felii de cartof fierte în bilă de bou suplimentată cu glicerol, Calmette și Guérin de la Institutul Pasteur din Lille - Franța, au creat un vaccin atenuat, bacilul Calmette-Guérin sau BCG (7). Prima vaccinare umană a fost făcută de către Weil-Halle la Paris în 1921 la un copil, pe cale orală, cu câteva doze succesive, și prima campanie de imunizare în masă a persoanelor tuberculin-negative a început în Polonia în anul 1948 (8). Pentru administrare au mai fost folosite calea intradermică și calea percutanată prin înțepături multiple sau scarificare. Începând din anul 1974, vaccinarea BCG a copiilor a fost inclusă în Programul Extins de Imunizare al OMS și ca urmare au fost vaccinați până în prezent mai mult de trei miliarde de copii pe glob, cu o rată de aproximativ 100 de milioane de vaccinări anuale (5).

Studiile experimentale indică faptul că mecanismul de protecție prin vaccinarea BCG constă în reducerea diseminării hematogene a bacililor de la locul infecției primare mediată de limfocitele $\mathrm{T}$ cu memorie induse de prima expunere la BCG. Nu există nicio dovadă însă că BCG ar reduce riscul unor infecții ulterioare cu bacilii TB, dar a fost dovedit faptul că el previne formele de TB care depind de diseminarea hematogenă a bacililor. Această inhibiție a diseminării hematogene reduce riscul progresiei directe a infecției către boală, precum și a reactivării endogene a bolii. Deoarece este vorba despre reducerea riscului privind progresia rapidă a infecției către boală, dar nu și a riscului de infectare, se poate concluziona că există o diferență privind efectul protectiv al BCG, depinzând de patogenia TB și relația infecție-boală în tuberculoză $(8,9)$.

Este demonstrat faptul că vaccinarea BCG previne TB diseminată; se includ aici meningita TB și miliara TB, afecțiuni cu mortalitate crescută la sugari și copii mici. În primele lor studii privind vaccinarea BCG, Calmette și Guérin au observat însă că vaccinarea BCG nu numai că protejează copiii împotriva deceselor prin TB, dar și că reduce mortalitatea generală a copiilor care nu suferă de TB. Această temă a fost ignorată în deceniile următoare. Mai recent însă ea a fost reluată și au fost prezentate date epidemiologice noi în sprijinul ei; în câteva țări cu venituri reduse, studiile efectuate au evidenţiat faptul că vaccinarea BCG este corelată cu reducerea mortalității infantile generale (10).

Vaccinarea BCG trebuie practicată ca parte a programelor naționale de imunizare a copiilor în funcție de nivelul endemiei TB din fiecare țară. În 2015, 163 de țări au raportat că efectuează vaccinarea BCG ca standard al acestor programe; 
102 au raportat o acoperire de 90\%. OMS recomandă ca în țările cu endemie TB crescută să se administreze o singură doză de vaccin tuturor copiilor cât de repede se poate după naștere, ca parte a programelor de imunizare (2).

Ca urmare a celor expuse, este clară necesitatea unui vaccin mai eficient decât BCG, în special pentru a reduce riscul infecției cu $M t b$ și riscul progresiei infecției la boala activă la adult. Deși există mai mult de 10 candidați în diverse etape de studiu (Tabelul 1), un nou vaccin anti-TB care să respecte toate condițiile de eficiență și siguranță nu este de așteptat în viitorul apropiat.

\section{DIFICULTĂṬI ASOCIATE DEZVOLTĂRII UNUI NOU VACCIN}

Complicațiile apărute în studiul $M t b$ în laborator sunt numeroase și datorită naturii sale complexe, $M t b$ reprezintă o provocare unică pentru cercetători (6).

\section{Considerații de biosecuritate}

Când un cercetător decide să investigheze dezvoltarea unui vaccin împotriva $M t b$, una dintre primele considerații de care trebuie să țină seamă este siguranța celor care lucrează cu micobacteriile. În laboratoarele de cercetare, $M t b$ este considerat a avea nivel 3 de biosiguranță; acest nivel este atribuit de OMS germenilor care au un potențial ridicat de risc la nivel individual și care pot cauza leziuni serioase persoanelor infectate, dar cu un risc scăzut pentru comunitate. Variatele măsuri de siguranță ce trebuie puse în joc includ proceduri de laborator, facilități de construcție (camere separate cu presiune negativă), echipament de securitate și siguranță.

\section{Multiplicarea lentă a germenilor}

$M t b$ este un germene cu multiplicare lentă, timpul sau de dublare fiind de aproximativ 24 de ore. Din acest motiv, când este planificat un experiment pe animale infectate, cercetătorii trebuie să ia în consideraţie trecerea unei durate suficient de mare de timp între inițierea experimentului și finalizarea studiului. Astfel, dacă unui șoarece nevaccinat i se administrează o doză mică de aerosoli infectați cu $M t b$ virulent, pot să treacă 3-4 săptămâni înainte ca leziunile granulomatoase vizibile să se formeze la nivel pulmonar. În cazul cercetărilor imunologice, șoarecii sunt sacrificați în 30 până la 120 de zile după infecție pentru a putea evidenția reacțiile imune pe termen lung și scurt și a determina dacă vaccinul a avut vreun efect asupra reducerii numărului micobacteriilor.

\section{Stadiile bolii}

La om există 4 stadii ale infecției cu $M t b$ : infectare, latență, boală activă și transmitere (11). În fiecare dintre aceste stadii, proteinele exprimate de către organism variază semnificativ și din acest motiv protecția asigurată într-unul dintre stadii nu protejează în altul. După infecția primară, la un individ imunocompetent, infecția poate să progreseze către o tuberculoză latentă (LTBI). Sistemul imun al unei persoane cu cu LTBI conține efectiv micobacteria chiar dacă din punct de vedere clinic persoana nu prezintă TB activă, dar iși va dezvolta celule cu memorie împotriva antigenelor $M t b$. Când $M t b$ este în stadiul de multiplicare lentă sau non-replicativă exprimă un set diferit de antigene decât în timpul stadiului de infecție primară al ciclului de viață. Este interesant de notat însă faptul că persoanele infectate cu Mtb și care evoluează către LTBI nu sunt protejate de reinfecție.

De dorit, cel mai bun vaccin ar trebui să asigure protecție în toate stadiile infecției, astfel încât el ar trebui să fie eficient în infecția primară, latentă, reactivarea endogenă și reinfecție.

\section{Vaccinarea persoanelor imunocompromise}

TB este ucigașul numărul unu al persoanelor infectate HIV. Recrudescența infecțiilor cu Mtb în anii 1990 a fost atribuită tocmai amplorii luate de epidemia HIV. O infecție cu HIV conduce la reducerea numărului de limfocite T-CD4 și se 
crede că aceasta este cauza unei mai mari susceptibilități la $M t b$ a celor mai multe persoane. Infecția HIV poate să altereze funcția macrofagelor și a celulelor $M t b$-specifice implicate în uciderea germenului. Sistemul imun al persoanelor infectate HIV este, din aceste motive, incapabil să controleze infecția cu $M t b$, fapt ce are ca rezultat reactivarea bolii. De asemenea, copiii infectați HIV nu sunt capabili să producă un răspuns robust de tip Th1 când sunt vaccinați BCG, existând astfel un risc semnificativ crescut de diseminare a BCG după vaccinare. Un alt grup de imunocompromiși care trebuie luați în considerație sunt cei care trăiesc în condiții de sărăcie, au o alimentație deficitară, cei cu diabet, deficiențe ale vitaminei D, insuficiență renală, cu tratamente imunosupresive, fumătorii sau bolnavii cu alte dependențe.

\section{Vaccinarea pre- sau post-expunerea la patogen}

În cazul TB, este important să se ia în considerație dacă vaccinul va fi administrat pre- sau post-expunere la $M t b$. Sistemul imun al unei persoane va răspunde diferit la vaccin dacă aceasta a fost expusă anterior la $M t b$. În cazul în care sistemul imun a avut un răspuns inițial la antigenele particulare ale $M t b$, dar care nu poate asigura protecția, este necesar a se găsi noi metode de activare imună, mai eficiente decît vaccinarea BCG (pre-expunere). În plus, din cauza unei prevalențe înalte a $M t b$ în țările cu endemie crescută, este necesar probabil un vaccin care să fie eficient și post-expunere.

\section{Tulpini de laborator versus tulpini izolate clinic}

Micobacteriile izolate de la bolnavi sunt adesea complet diferite față de tulpinile utilizate în mod frecvent în practica de laborator. Laboratoarele, datorită necesității repetabilității experimentelor lor, trebuie să menţină tulpinile nemodificate. Actualmente există câteva tulpini utilizate în mod curent în laboratoarele din întreaga lume (H37Rv, HN878, Erdman, CDC1551 etc.) care au caracteristici diferite privind virulența și compoziția lor antigenică. Din nefericire, aceste tulpini pot să difere semnificativ față de tulpinile de micobacterii izolate de la bolnavii infectați. Tulpinile ce se găsesc „în mod sălbatic" prezintă în mod constant schimbări și mutații dependente de factori de selecție variați. Printre acești factori de selecție se includ tratamentele incomplete sau rezistența unei persoane netratate la micobacterii. Suplimentar, există o rată de mutație naturală la nivelul genomului tuturor organismelor, independentă de factorii de selecție, datorată erorilor de replicare ale ADN-ului sau deteriorării ADN-ului. Factorii de selecție și modificările mutaționale observate la nivelul tulpinilor izolate de la bolnavi sunt mult mai evidente la micobacteriile multi-, extrem și total rezistente la droguri. Cu toate că se speră că există suficient de multe similarități între tulpinile de laborator și cele izolate de la bolnavi astfel încât vaccinarea împotriva unora să asigure protecție pentru toate formele de $M t b$, trebuie luată în considerare mutația constantă a tulpinilor „sălbatice“.

\section{Dificultăți legate de proprietățile intrinseci ale Mtb}

$M t b$ este intracelular, ceea ce înseamnă că sistemul imun trebuie să aibă abilitatea de a recunoaște și a elimina germenul din celulele infectate ale gazdei fără să îi cauzeze acesteia prejudicii. $M t b$ și-a stabilit câteva modalități prin care poate să scape recunoașterii de către sistemul imun al gazdei. Cele mai multe dintre aceste mecanisme se învârt în jurul căilor de a menţine patogenul în stare dormantă în interiorul macrofagelor. Această blocare a fagocitozei previne procesul de prezentare al antigenelor $M t b$. Prezentarea antigenelor este esențială pentru a recunoaște că un antigen este străin și necesită să fie eliminat, precum și pentru crearea unei memorii imune. Mtb poate însă să scape suprimării prin abilitatea sa de a regla decesul cauzat de necroza sau apoptoza celulelor gazdei. Toate aceste metode de evitare ale eliminării pe 
care le dezvoltă $M t b$, servesc pentru a-l menține în interiorul macrofagelor unde el poate trăi zeci de ani sub forma unei infecții latente. Din aceste motive, când se proiectează un vaccin, este necesară activarea sistemului imun de o asemenea manieră încât gazda să depășească aceste metode de evaziune ale germenului și să recunoască celule infectate care trebuie distruse.

\section{Direcții actuale de dezvoltare privind vac- cinarea anti-Mtb}

Atât scăderea incidenței globale a TB, dar mai ales perspectiva amenințătoare a creșterii incidenței MDR-TB accentuează necesitatea unor noi vaccinuri anti-TB care să fie mai eficiente decât BCG în prevenția bolii. Studiile clinice în curs pentru dezvoltarea unor noi vaccinuri sunt prezentate în Tabelul 1.

Structura acestor vaccinuri include BCG recombinant (rBCG), derivate celulare, vectori virali recombinanți, combinații proteice și adjuvante, extracte de micobacterii. Scopul acestor vaccinuri este de a preveni infecția (administrare pre-expunere), de a preveni progresia infecției spre boală sau reactivării unei LTBI (postexpunere) sau imunoterapeutic, împreună cu drogurile specifice.
Vaccinurile TB aflate actual în diferite stadii ale unor studii clinice reflectă câteva strategii de imunizare:

1) Un vaccin utilizat per primam pentru a înlocui BCG-ul, fie cu un rBCG sau cu o tulpină de $M t b$ atenuată genetic, conferă o mai mare siguranță și eficacitate protectivă și poate fi administrat precoce înainte de expunerea la Mtb (13). Se intenționează utilizarea unor asemenea vaccinuri la nou născuți sau copiii mici, în momentul în care sistemul imun individual nu a fost expus încă la infecția naturală cu $M t b$ sau cu alte micobacterii. Se presupune că vaccinurile candidate viabile vor înlocui BCG sau vor amplifica efectul acestuia, încă unicul vaccin ce se administrează pe cale largă în cursul primei săptămâni de viață.

2) Un alt tip de vaccinuri accentuează răspunsul imun, atât precoce cât și tardiv în timpul vieții, atunci când LTBI s-a instalat deja. Acest tip de vaccinuri se poate administra împreună cu alte vaccinuri în copilărie, în cursul primului an de viață, dar și în oricare alt moment, la școlari, adolescenți sau chiar adulți, când protecția indusă de BCG începe să se diminueze. Vaccinurile de acest tip pot să utilizeze fie vectori virali, unități adjuvante sau celule întregi inactivate prin

TABEL 1. Vaccinuri anti-TB aflate actual în studii clinice $(2,3,11,12)$

\begin{tabular}{|c|c|c|c|c|}
\hline Numele vaccinului & Scop & Tip & Fază & Dezvoltator \\
\hline Ad5 Ag85A & Pre-, post-expunere & Vector viral & 1 & McMaster University, CanSino \\
\hline TB/Flu-04L & Pre-, post-expunere & Vector viral & 1 & Research Ins tute for Biological Safety Problems \\
\hline Crucell Ad35 + MVA85A & Pre-, post-expunere & Vector viral & 1 & Crucell, Oxford University, Aeras \\
\hline ChAdO $\times 1.85 \mathrm{~A}$ & Pre-, post-expunere & Vector viral & 1 & Oxford University \\
\hline MTBVAC & Pre-expunere & Micobacterian & 1 & $\begin{array}{l}\text { University of Zaragoza, Biofabri, TuBerculosis } \\
\text { Vaccine Ini a ve (TBVI) }\end{array}$ \\
\hline MVA85A (aerosol) & Pre-, post-expunere & Vector viral & 1 & Oxford University \\
\hline MVA85A-IMX313 & Pre-, post-expunere & Vector viral & 1 & Oxford University, Imaxio \\
\hline DAR-901 & Pre-, post-expunere & Micobacterian & Illa & Dartmouth University, Aeras \\
\hline ID93 + GLA-SE & Pre-, post-expunere & Proteine/adjuvante & Ila & Infec ous Disease Research Ins tute, Aeras, Aeras \\
\hline RUTI & Imunoterapeu c & Micobacterian & Ila & Archivel Farma, S.L \\
\hline Hybrid $1+$ IC31 & Pre-, post-expunere & Proteine/adjuvante & Illa & SSI, Valneva \\
\hline Hybrid 4/Aeras-404 + IC31 & Pre-, post-expunere & Proteine/adjuvante & Illa & SSI, Sanofi Pasteur, Valneva, Aeras \\
\hline Hybrid 56/Aeras-456 + IC31 & Pre-, post-expunere & Proteine/adjuvante & IIa & SSI, Valneva, Aeras \\
\hline $\mathrm{M} 72+\mathrm{AS01E}$ & Pre-, post-expunere & Proteine/adjuvante & IIb & GlaxoSmithKline, Aeras \\
\hline VPM 1002 & Pre-expunere & Micobacterian & IIb & $\begin{array}{l}\text { Serum Ins tute of India, Vakzine Projekt } \\
\text { Management, TBVI, Max Planck Ins tute for } \\
\text { Infec on Biology }\end{array}$ \\
\hline M. vaccae & Imunoterapeu c & Micobacterian & III & Anhui ZhifeiLongcon, China \\
\hline
\end{tabular}


căldură și impun un set diferit de antigene (14). Faptul că boala tuberculoasă ce apare mai târziu pe parcursul vieții se poate produce atât prin reactivare endogenă, cât și prin reinfecție exogenă, trebuie să se reflecte în compoziția antigenică a unui vaccin eficient anti-TB.

3) Un vaccin terapeutic împotriva $T B$ activă. Vaccinurile terapeutice au drept țintă bolnavii cu TB activă, fie pentru a scurta durata chimioterapiei standard, fie pentru a se asocia tratamentului folosit la pacienții cu MDR-TB și XDRTB. Un candidat de acest tip este preparatul din Mycobacterium vaccae care a fost folosit pentru a trata pacienții cu coinfecție HIV și miliară TB, cu prognostic rezervat. RUTI, un preparat semipurificat din $M t b$ ucise, se află în faza II de studiu la bolnavii infectați și non-infectați HIV cu LTBI.

Factorul comun al acestor strategii de vaccinare este concentrarea atenției asupra dobândirii unei imunități mediate celular prin inducerea Th1 citokinelor (IFN- $\gamma$, TNF- $\alpha$ și IL-2), produse atât de celulele T-CD4, cât și de cele T-CD8. Aceste citokine activează alte celule capabile să inhibe creșterea $M t b$ (14).

\section{CONCLUZII}

Vaccinul BCG, în ciuda utilizării sale extinse, nu asigură protecția necesară. Dezvoltarea unor vaccinuri eficiente impune o înțelegere mai bună a răspunsului imun protectiv la $M t b$ și a patogeniei bolii. Disponibilitatea tuturor secvențelor genomice a mii de tulpini izolate de $M t b$ și evidențierea recentă a importanței coevoluției gazdă-germene trebuie să ajute la proiectarea a diferite modalități de abordare ale vaccinării. Suntem încă departe de a înțelege de ce sistemul imun natural (care protejează 90\% dintre persoanele infectate să dezvolte o TB activă) eșuează la 10\% dintre cei infectați și de ce răspunsul imun adaptativ în tuberculoză nu ne protejează de infecțiile repetate $(15,16)$.

Deși recent s-au făcut importante progrese științifice, rămân încă lacune majore privind înțelegerea biologiei germenului și răspunsului uman la infecția cu $M t b$. Actualele provocări privind controlul TB, precum infecția HIV, MDR-TB și mai recent XDR-TB pot depăși progresele înregistrate, ameninţând abilitatea noastră de a controla boala.

Calitățile unui vaccin ideal includ siguranța și eficacitatea pentru nou-născuți, copii și adulți (inclusiv pentru cei infectați HIV); eficiență împotriva tuturor formelor de TB incluzând și MDR-TB; comoditatea utilizării (calendar de vaccinare și noninterferența cu alte imunizări în copilărie); o formulă care poate fi fabricată practic pe scară largă, stocată și administrată în condiții tehnice accesibile.

Studiile clinice aflate în curs de desfășurare evaluează ipotezele privind variabilitatea eficacității BCG. Modificarea metodologiei administrării BCG, precum și administrarea unor noi vaccinuri tinde fie să înlocuiască, fie să intensifice efectul vaccinării BCG (17). 